Currículo sem Fronteiras, v. 20, n. 2, p. 348-371, maio/ago. 2020

\title{
ESPIRALIDADES: arte, vida e presença na pequena infância
}

\author{
Marina Marcondes Machado \\ Universidade Federal de Minas Gerais - UFMG
}

\begin{abstract}
Resumo
Este artigo quer propor novos termos para a Educação Estética na primeira infância: aproximando vida e arte e tendo como ponto de partida a fenomenologia de Maurice Merleau-Ponty (1990a, 1990b), a autora repensa as linguagens artísticas como âmbitos artístico-existenciais: teatralidades, corporalidades, espacialidades e musicalidades. Esta nova visada e vocabulário conversam com a Estética Relacional de Bourriaud (2009), autor que define arte como experimentação estética compartilhada. Os estudos da autora aproximam fenomenologia, infância e arte contemporânea para assim, por meio também de sua experiência com crianças como professora artista, desenhar uma Abordagem Espiral para a iniciação estética nos primeiros anos de vida. Neste caminho, o adulto condutor de processos criativos desprende-se dos conteúdos próprios e específicos de cada linguagem artística para absorver um currículo em artes cujo mote é existencial e híbrido. A autora argumenta que esta maneira de trabalhar é bastante próxima da criança pequena e de suas brincadeiras, produções, narrativas e expressividade: a criança é um ser total e seus modos de ser e estar se apresentam repletos de polimorfismo e onirismo, e sua leitura do mundo é não representacional.
\end{abstract}

Palavras-chave: educação estética; primeira infância; ensino de arte; abordagem espiral.

\begin{abstract}
This article aims to propose new terms for Aesthetic Education in early childhood: approaching life and art and starting with Maurice Merleau-Ponty's phenomenology (1990a, 1990b), the author rethinks artistic languages as artistic-existential environments: theatricalities, corporalities, spatialities and musicalities. This new view and vocabulary dialogues with the Relational Aesthetics of Bourriaud (2009), who defines art as shared aesthetic experimentation. The author's studies have approached phenomenology, childhood and contemporary art, and thus, through her experience with children as an artist teacher, draws a Spiral Approach to aesthetic initiation in the early years of life. In this way, the adult driver of creative processes detaches himself from the specific contents of each artistic language to absorb a curriculum in arts whose motto is existential and hybrid. The author argues that this way of working is very close to the small child and his/her games, productions, narratives and expressiveness: the child is a total being and his/her ways of being are full of polymorphism and daydreaming, and his/her conception of the world is non-representational.
\end{abstract}

Keywords: aesthetic education; early childhood; art teaching; spiral approach. 


\section{Introdução: maturidade de um percurso vivido}

A proposta e o pensamento discutidos aqui delinearam-se, lenta e homeopaticamente, a partir da experiência de quase trinta anos como artista-professora, na somatória dos mais diversos momentos de reflexão sobre as relações entre arte e educação, especialmente acerca do teatro ensinado por mim junto a crianças e na prática de formação de adultos, professores leigos em arte. Nas possíveis conversas entre o fazer teatral e outros fazeres artísticos, procurei trilhar o caminho daquilo que, na contemporaneidade, se nomeia hibridismo - algo que o encenador Ilo Krugli ${ }^{1}$, diretor do Teatro Ventoforte, já denominava por arte integrada na década de 1970, e muitos outros nomearam, em suas práticas artísticas e educacionais, nem tanto tempo atrás, por integração de linguagens - até que outros artistas e pensadores mais radicais formularam, de modo propositivo e vivencial, a dissolução das fronteiras entre as artes: processo desenhado de modo histórico e situado, construto de diferentes artistas e performers, inspirados por exemplo em Christoph Menke (2013) ou Allan Kaprow (2003). Começa assim minha espiral ${ }^{2}$ do conhecimento artístico e da hipótese de uma experiência estética inserida nos modos de vida da criança: partirei especialmente do foco na relação adulto-criança, como abertura para a reflexão que aqui se inicia, na pretensão de contribuir para a discussão acerca do currículo em artes na pequena infância.

Meu pensamento acerca do ensino de arte para crianças acontece em camadas, sobreposições, tessituras tramadas durante meu percurso como pesquisadora, da juventude (no convívio na Casa do Ventoforte, nos anos de 1980-1983) ao Trabalho de Conclusão de Curso em Psicologia na PUC-SP, seguindo-se o Mestrado em Artes na ECA-USP e o Doutorado em Psicologia da Educação, também na PUC-SP, estudos concomitantes com minha prática docente com crianças na Escola Municipal de Iniciação Artística de São Paulo (EMIA-SP). No pós-doutoramento em Pedagogia do Teatro, em 2009, elaboro uma importante forma-conteúdo que sintetiza meu trabalho até ali: a concepção da criança performer $^{3}$, síntese de um pensamento sobre a primeira infância, desdobramento dos diálogos com aqueles que pensam a arte como algo pertencente à vida mesma, ordinária e cotidianamente:

Penso que não só no desenho, no teatro ou nas brincadeiras estão os caminhos performativos da criança pequena. Muito pelo contrário: se a visão de infância que enxerga a criança como performer fosse assim utilitária, porque focada especificamente nas linguagens infantis tal como pensadas por educadores, estaríamos incorrendo em um erro empobrecedor. Digamos que permitir à criança ser performer revela uma conduta, uma maneira de estar, “(...) uma primeira maneira de estruturar as coisas" - esse é o modo como Merleau-Ponty (1990b, p. 268) define o desenho não representacional. Os estilos de chupar chupeta, dormir no colo ou no berço, a escolha do brinquedo preferido, a coceira na cabeça, cada gesto poderá ser lido como ato performativo. É algo que nos fará íntimos da Antropologia, de diversos estudos culturais, daquilo que se chama inventariar. $\mathrm{O}$ adulto observador, que inventaria cada modo de ser das crianças ao seu redor, é receptor das coisas que a criança expressa ou comunica. (Machado, 2010a, p. 130) 
Pensar a criança como performer não seria dar destaque apenas ao processo de pesquisa artística subjetivo e individual, seja do professor ou do aluno - o que incorreria no erro que os fenomenólogos chamam de "psicologismo" - mas sim fazer foco nas inúmeras possibilidades intersubjetivas dos contextos e das situações expressivas. A educação e a iniciação nas artes, neste prisma, se definem como campo relacional, e todas as experiências, por mais íntimas e singulares, brotam de situações coletivas e compartilhadas - portanto também exteriores -, acontecimentos nos quais cada um e todos mergulham, à sua maneira, a partir de suas possibilidades. Aos educadores, caberá rabiscar, inventar, delinear e propor situações de mergulho. No entanto não sabemos de antemão o que vai acontecer na piscina depois!

Desde junho de 2012 trabalho como docente na Licenciatura em Teatro da Universidade Federal de Minas Gerais, e tenho proposto o uso da expressão ato performativo em substituição à categoria atividade de artes - com o objetivo de obter, como princípio gerador, foco naquele que aprende arte. Aquele que ensina, na perspectiva desta argumentação, tornase uma espécie de modelo zen para aquele que aprende; por meio da corporalidade adulta, em seu corpo encarnado, suas prerrogativas, conexões, estudos sobre arte e infância, revelam algo sobre seu percurso, biografia e poéticas próprias; e aquele que apreende, exercita, concretiza (não imita!) o fazer artístico é o grande protagonista, performer de descobertas significativas: expressividade de sua existência, com os outros e no mundo compartilhado. Foco no outro é um dos ensinamentos mais peculiares do método fenomenológico.

Quero trazer ao público leitor esta outra via, nunca de mão única, nem tampouco previamente acabada - caminho que revela, sempre, um trabalho em processo: pesquisa encarnada de uma maneira de ensinar arte e ser ensinado, e doar significado à existência humana; incluindo, em nossa corporalidade de professor-artista, pesquisador e performer, tudo de inumano que também carregamos. Este caminho possível surgiu em meu trabalho especialmente a partir do encontro com a fenomenologia da criança, no estudo cuidadoso de parte da obra de Maurice Merleau-Ponty - aquela voltada à psicologia e à pedagogia da criança, editada nos chamados Cursos na Sorbonne, e na busca de íntimas relações entre o modo de ser e estar da criança pequena com propositivas da arte contemporânea. Os Cursos na Sorbonne são pouco divulgados no Brasil; foram ministrados por Merleau-Ponty, entre 1949-1952, e publicados postumamente, a partir de anotações dos alunos, mas revisadas pelo filósofo ainda quando vivo. Maurice Merleau-Ponty é considerado um dos mais importantes filósofos franceses do século XX. Nasceu em 1908 e faleceu precocemente, em 1961; na década de 1930, fez parte de uma juventude que transformou a tradição filosófica na França: uma geração de descontentes com a tradição do ensino de filosofia e que propunha que o conhecimento filosófico falasse do mundo "em carne e osso". A filosofia da existência na França apresenta dois grandes nomes e duas grandes obras: Sartre e Merleau-Ponty.

Somado ao estudo fenomenológico da criança, destaco na elaboração deste artigo a conversa com noções centrais da psicanálise inglesa, tal como preconizada por D. W. Winnicott (1994) em sua importante teoria da criatividade, e o encontro com as possibilidades de uma estética relacional, esboçada pelo curador e crítico de arte Nicolas 
Bourriaud (2009) no final do século XX, em livro de mesmo nome. Busquei um tripé entre uma noção de infância, uma noção de arte e uma noção de educação estética junto a crianças pequenas.

É minha pergunta: o que muda no campo da educação estética das crianças se adotarmos a visão de infância do filósofo Merleau-Ponty? A discussão que se seguirá é a elaboração ampliada e revisada de um ensaio escrito para o IV Concurso Mário Pedrosa de Ensaios sobre Arte e Cultura Contemporânea (Fundação Joaquim Nabuco / FUNDAJ) de monografias acerca do ensino de arte e arte contemporânea, no qual o texto escrito por mim, intitulado "Fenomenologia de Merleau-Ponty e as relações entre educação, arte e vida na pequena infância: rumo a uma Abordagem Espiral no ensino de arte", foi vencedor (ensaio escrito em 2011 e vencedor do prêmio em 2012). O texto permaneceu inédito até o momento, uma vez que o Edital previa que os direitos autorais seriam propriedade da Fundação Joaquim Nabuco por cinco anos.

Escolhi como pano de fundo ou elo entre as sessões do texto, epígrafes que se encontram em um importante e paradigmático texto do artista, professor na Universidade de Stanford e teórico da educação Elliot Eisner, artigo intitulado "O que pode a educação aprender das artes sobre a prática da educação?" e publicado na revista Currículo sem Fronteiras em dezembro de 2008. O modo como Eisner faz, sintético e profundo, sobre o importante lugar das artes no campo do conhecimento humano, em conferência proferida na Dewey Society, é admirável, e procurei homenageá-lo aqui.

\section{O método fenomenológico é uma visão de mundo: para aprender com crianças}

O que nós podemos fazer é gerar outras visões de educação, outros valores para dirigir a sua concretização, outras suposições sobre as quais se possa construir uma concepção de prática escolar mais generosa.

Elliot Eisner

A fenomenologia não constrói uma teoria sobre a criança, pois a fenomenologia é método filosófico e, portanto, constrói e revela modos de pensar. A maneira fenomenológica de pensar as relações adulto-criança inicia-se por tornar visível quem somos e quem a criança é, a partir de uma atitude compreensiva em psicologia e pedagogia da criança. É algo que não acontece por meio do estudo de teorias do desenvolvimento, mas, antes, por meio da adesão a um método observacional descritivo e cuidadoso que mergulha no cotidiano, nas coisas tal como elas se nos apresentam. A fenomenologia da infância será a descoberta, em situação, ou seja, contextualizada e de forma relacional, dos mundos de vida da criança, pelas descrições adultas acerca das relações que mostram quem ela é e como está: como ela apresenta-se a si, com os outros, no mundo. 
Brincando com o dado cultural do Jardim de Infância criei, em minha tese de doutorado tornada livro ${ }^{4}$ (Machado, 2010b), a partir de anos de estudo do entrelaçamento entre fenomenologia e infância, a imagem d'A Flor da Vida: um desenho de "flor-palito" cujas pétalas se constituem pelos existenciais, a saber: pela outridade (relação criança-outro), pela corporalidade (relação criança-corpo), pela linguisticidade (relação criança-língua), pela temporalidade (relação criança-tempo), pela espacialidade (relação criança-espaço); e o cabo da flor (que a enraizará no solo) é traçado pela mundaneidade (relação criança-mundo). Para regar a Flor da Vida, precisamos da mão do adulto: gesto, cuidado e responsividade; o adulto apresenta a criança ao mundo e à cultura compartilhada - na qual, aliás, ela já nasceu imersa. As pétalas e o cabo da Flor da Vida são parâmetros para os estudos descritivos da criança e suas relações.

A fenomenologia da criança aproxima-se do caminho antropológico por buscar narrativas descritivas densas em um trabalho de fundo etnográfico e rico em contextos relacionais, como ponto de partida para o adulto perceber como educa e acompanha a criança cotidianamente. Olhar para como trazemos as crianças ao mundo, e como mostramos o mundo a elas, em situações de convivência, é parte importante deste jeito de pensar a infância, que pode trazer novos ares para as relações entre adultos e crianças, além e aquém das clássicas teorias desenvolvimentistas.

Assim os apontamentos que se seguem, bem como minha obra como um todo, dialogam com os Cursos na Sorbonne de Merleau-Ponty (editados no Brasil primeiramente em 1990 pela Editora Papirus, em dois volumes, e depois pela Editora Martins em 2006 em um volume só) para convidar os adultos leitores a pensar situações relacionais: como as crianças vivem e compreendem o espaço, o tempo, a relação com os outros, o mundo, a cultura, a língua materna e seu corpo próprio? A partir da fértil poética de uma gênese fenomenológica do eu, desenha-se uma concepção de criança. Hoje, passadas praticamente duas décadas do século XXI, a prerrogativa merleau-pontiana poderia somar-se aos estudos das culturas da infância ${ }^{5}$, campo de pesquisa da Antropologia da criança e da Sociologia da infância.

O lugar das experiências estéticas, na infância contemporânea, será aqui desenhado a partir da convivência entre adultos e crianças, que, como concebe o filósofo, habitam o mesmo mundo, mas o apreendem de formas distintas. São as principais noções discutidas por Merleau-Ponty e que distinguem o modo próprio das crianças habitarem o mundo: o polimorfismo, o onirismo e a não representacionalidade, em seus modos de ser e estar no mundo.

O polimorfismo é discutido nos Cursos na Sorbonne em um interessante subcapítulo denominado Método da psicologia da criança. Esta noção nos leva a compreender a inteligência da criança pequena como inteligência vivida no corpo, cuja capacidade plástica a possibilita concentrar-se simultaneamente em diferentes ações, algo que o adulto muitas vezes lê noutra chave, como desatenção e imaturidade. Diz Merleau-Ponty:

É preciso conceber a criança não como um "outro" absoluto nem como "o mesmo" que nós mas como polimorfa. (...) 
Lèvi-Strauss propõe generalizar essa noção e admitir que a criança é polimorfa do ponto de vista cultural: há não uma mentalidade infantil mas um polimorfismo infantil. A criança, não estando ainda integrada na nossa cultura, pode apresentar condutas que lembram certas condutas patológicas ou "primitivas".

A semelhança aparente entre as mentalidades patológicas, primitivas e a mentalidade infantil vem em razão de que a criança não está ainda assumida pela sua futura formação cultural (Merleau-Ponty, 1990b, p. 220)

O filósofo também aponta o modo onírico da criança habitar o mundo - a criança viveria na "zona da ambiguidade do onirismo" (1990a, p. 223), revelando sua capacidade para mesclar realidade e fantasia, ao viver "uma ordem que não é uma ordem racional mas que também não é o caos" (1990b, p. 229). O onirismo está presente cotidianamente na vida das crianças como modo de ser e estar e mostra-se aos adultos especialmente em desenhos, pensamentos e sentimentos, e no brincar de faz de conta: ação que o pesquisador Manuel Sarmento brilhantemente traduziu por "um modo narrativo" de "estruturação não literal das condições de existência" (Sarmento, 2004, p. 16).

A terceira forte característica da criança pequena, discutida nos dois volumes dos Cursos na Sorbonne por Merleau-Ponty, é a não representacionalidade, algo primordial da primeira infância, na leitura do filósofo. Sinônimo da profunda adesão da criança ao outro, às coisas, ao mundo, a noção de não representacionalidade nos anos iniciais revela uma crítica contundente de Merleau-Ponty às pesquisas sobre inteligência e fases de desenvolvimento da criança naquele momento histórico: nos primeiros anos de vida, a criança seria incapaz de distanciar-se - e, portanto, não possuiria "representação sobre o mundo" - "a própria ideia de representação de mundo supõe a possibilidade de encontrar na criança uma tese sobre o mundo" (Merleau-Ponty, 1990b, p. 227) o que não seria possível; sua experiência, segundo o filósofo, não é categorial nem tética, mas vivencial; ela não representa o mundo, ela o vive; ela não atua, mas presentifica: estados, situações, sentimentos-pensamentos. Noutra passagem, Merleau-Ponty afirma que falar de uma verdadeira representação de mundo na criança subentenderia "uma organização conceitual da experiência infantil que pode ser formulada em proposições expressas. Supor na criança alguma coisa desse gênero é talvez desconhecer o essencial da mentalidade infantil, a saber, a ignorância do problema como tal" (1990a, p. 238).

\section{Ensino de arte e olhares metodológicos}

As lições que as artes ensinam não são apenas para os nossos estudantes, elas são também para nós.

Elliot Eisner

Imagine o leitor três tipos de lentes para olhar as crianças no mundo, sua arte e vida imaginativa: a primeira, ligada ao surgimento de ateliês livres e a práticas da chamada "livre 
expressão", a qual nomearei, de forma humorada, lente de óculos espelhado, remetendo intencionalmente à estética da década de 1970; a segunda lente, ligada a uma premente e histórica necessidade de rever a noção de "livre expressão", nos anos de 1990, por meio de abordagens teóricas que consideram a criança e o jovem atores sociais em processo educativo, sempre inseridos em um tempo histórico e um espaço político-social determinado - a essa lente chamarei de lente de óculos de grau, uma lente própria para enxergar teorias; e por último, imaginemos a lente do olhar fenomenológico, que procura enxergar a criança e sua capacidade artística tal como se nos apresentam, no tempo-espaço cotidiano do convívio: lente frágil, é fato, mas que abre caminhos para uma possível estética relacional, construída, de modo experiencial e antropológico, entre adultos e crianças. Esta terceira lente seria uma terceira via entre empirismo e teoria, e pode dialogar, na contemporaneidade, com os Estudos Sociais da Infância.

\section{1 Óculos espelhado: para enxergar Paz e Amor, com foco na vivência}

Vestir este óculos é revelar a estética que resumo na frase, que seria mote ou uma espécie de lema do professor-artista que o veste: "Deixa... Vai rolar!"; é algo ligado aos chamados ateliês livres, momento educativo de forte crença e necessidade de "livre expressão", algo herdado das construções/desconstruções do que seria arte, durante as décadas de 1960 e 1970. Vivi algo assim em minha juventude, tanto no Teatro Ventoforte, importante espaço do teatro para todas as idades, bem como no Ateliê Livre de Valdir Sarubbi, artista plástico paraense radicado em São Paulo. Naquela sintonia, o artista educador, com sua presença, dispõe os materiais, cria uma ambientação... e pronto: "Vai rolar!". Naquele contexto Herbert Read (1986) e Peter Slade (1978) eram exemplos de autores de cabeceira para quem almejava um ensino de arte livre, expressivo, não escolarizado.

Hoje é possível pensar que esta maneira de trabalhar com arte e expressão mostrava, de modo mais ou menos velado, mais ou menos displicente, uma forma de questionar o ensino tecnocrático dos anos da ditadura militar no Brasil, somado também a tudo que uma geração viveu no âmbito da contracultura, dos Beatles ao movimento hippie. Percebo que muitos hoje classificam, pejorativamente, a atitude do "Deixa, vai rolar!" de "espontaneísmo". Meu ponto de vista é de que esta etiqueta ou tarja pejorativa corre o risco de imprimir traços dogmáticos de como deve ser o ensino de arte, numa via racionalista, de mão única; não é bom etiquetar ou vetar a livre expressão pois precisamos continuar, agora e sempre, a buscar o gesto criativo espontâneo ${ }^{6}$ : e, para procurá-lo, precisamos acreditar nele. O psicanalista inglês D. W. Winnicott (1994), em sua teoria sobre o brincar e a criatividade, nos ensinou brilhantemente que uma dose de ilusão nos faz humanos - positivando, assim, o ato de fantasiar.

No olhar da estética dos olhos espelhados, eu mais sinto do que penso: e busco, em mim e nos alunos com quem convivo, uma tal verdade interior. Os pesquisadores Rejane Coutinho e Sidiney Peterson fazem menção a esta estética como "modelo de ensino de arte modernista", que revela "uma certa virgindade visual, a livre expressão e o desenvolvimento da sensibilidade e da criatividade" (2017, p. 9). 


\section{2 Óculos de grau: arte e ensino de arte com foco em teorias}

Vestimos este tipo de óculos e teorizamos nossa prática, e lá vamos nós ler sobre história da arte, psicologia do desenvolvimento, arte e psicanálise, de modo a elencar atividades "na medida", para cada etapa da criança. Vamos, nesta lente, ensinar pensando conteúdos por faixas etárias, querendo também desenvolver, nas crianças, habilidades "na medida" certa medidas dadas pelo estudo teórico e por uma boa grade curricular que nos guia, teoria e currículo como fios terra de uma prática emoldurada. Aqui o adulto persegue uma atitude propositiva, organizativa; fazemos planejamentos, sempre emoldurados pela teoria: desenhada pelas políticas públicas e ditada pelos teóricos da arte e da educação, da psicologia, da pedagogia. Esta perspectiva é importante, historicamente, como reação da comunidade acadêmica à Lei de Diretrizes e Bases, do ano de 1971, na qual o ensino de "educação artística" tornou-se obrigatório nas escolas brasileiras. A reação é positiva pois organizou cursos universitários de formação em Educação Artística, com duração de dois anos, cujo desdobramento crítico se dará mais tarde na organização universitária das especificidades das artes: inauguração das Licenciaturas em Artes Visuais, Teatro, Música e Dança nas universidades públicas e particulares do Brasil.

Assim, o olhar do óculos teórico formaliza o que estou vivendo no trabalho como professor de arte, em meus planejamentos, avaliações, supervisões. Nesta perspectiva, eu mais penso do que sinto, e a concretude material dos repertórios e repositórios, livros de arte, espaços museológicos, fóruns de discussão sobre arte e educação será a evidência de que o educador de óculos espelhado viajava em um mundo interior, particular, talvez alienado, em uma maneira de ser que aquele que veste óculos de grau vê como mentalista e idealista.

Este modo de trabalhar e ensinar arte é bastante típico no Brasil dos anos da década de 1990 em diante e foi delineado e emoldurado como Abordagem Triangular no ensino de arte, expressão cunhada por Ana Mae Barbosa; como vértices do triângulo, Ana Mae propôs os verbos conhecer, aprender e compreender, insistindo "na tese de uma alfabetização visual" (Bredariolli apud Coutinho e Peterson, 2010, p. 6). A partir das contribuições de Ana Mae e seus colaboradores, arte na escola não mais poderá ser considerada mera atividade - arte é um campo do conhecimento humano.

\section{3 Óculos com moldura e lentes fenomenológicas: para "olhar com os olhos" a experiência da criança mesma}

Nesta visão de uma armação de óculos com lentes para o olhar adulto enxergar um horizonte poético-existencial, o foco é a experiência da criança. Pergunta-se: quem são as crianças com as quais vou trabalhar e conviver por tal ou qual tempo? Onde vivem, como vivem? O que pensam, o que sentem, e, especialmente, o que já sabem sobre arte? E ainda: como estão hoje?

Aqui conectamos com a artesania de uma fenomenologia da criança, premência da aproximação adulta às culturas da infância, bem como estaremos atentos com a arte e o fazer artístico dentro e fora das instituições escolares/escolarizantes. Então será por meio deste 
óculos que encontrarei e enxergarei os atos performativos: dentro dos espaços escolares, sim, mas também fora da sala de artes - nas ruas, nas filas, nas brincadeiras, no gesto corriqueiro, ordinário, comum, que não notava anteriormente. Trata-se de ver e fazer ver "outra concepção de arte".

Qual concepção de arte?

Aquela na qual, você, leitor, deve se empenhar para descobrir, de forma relacional, com seus alunos e conectado à sua experiência: o professor que usa este (anti) óculos é, ele mesmo, um professor pesquisador, um professor narrador, um professor artista, um professor performer. Esta descoberta não descarta a crença no gesto espontâneo - nem tampouco joga no lixo as teorias! O que acontece é uma espécie de inversão de papéis, ou inversão da ordem dos fatores; desordeno o que já sabia para reordenar a partir da minha experiência, de modo contextualizado e antropológico; minha experiência de adulto não é descolada nem desvincula da experiência da criança com a qual convivo.

O caminho a seguir nesta terceira via não é simples (nem simplório); trata-se de gerar pensamento teórico a partir dos dados de realidade: eu preciso estudar, ler, me inspirar, saber observar em detalhes os fazeres das crianças, e saber descrever com densidade o que observei. Começo por um mergulho na prática educativa, para, com meu Diário de Bordo ${ }^{7}$ trabalhado cotidianamente, fazer reflexão, procurar continuidade e novas propositivas. Meus diálogos serão com as crianças e com a arte, para a arte, a partir da arte... Preciso procurar vias artísticas como forma de construção, conhecimento e expressão ao mesmo tempo! Preciso também me entusiasmar com a criação de uma poética própria. Este é um modo que dialoga com discursividades, com a pluralidade e com as possibilidades hermenêuticas, traduzidas na área das artes e da criação como a compreensão de mundos possíveis.

Quando não uso lentes espelhadas nem lentes teóricas, eu penso-e-sinto: não haveria, nesta concepção, dicotomia possível entre esses dois aspectos da vida adulta. Do mesmo modo, não vamos separar de modo hierárquico o saber do professor do saber do aluno. Haverá uma busca por verdades compartilhadas, na chave dialógica, entre adultos e crianças. Neste campo, neste modo de trabalhar, podemos gerar teorias, mas sempre a partir das experiências vividas cotidianamente, ou seja, nas próprias aulas de arte, por meio das observações e registros do ocorrido, e nos atos performativos compartilhados entre todos: muito debate e troca de energias, além de experiências vividas como espectador e leitor de obras de arte, das mais variadas. Aqui arte não será uma linguagem na qual adultos alfabetizam crianças: arte é um lugar para habitar.

\section{Abordagem Espiral para delinear um currículo na chave relacional}

Winston Churchill disse uma vez que primeiro projectamos os nossos edifícios e depois os nossos edifícios projectam-se a nós. Para parafrasear Churchill podemos dizer: primeiro projetamos o nosso currículo, depois o currículo projecta-se a nós. $O$ que eu penso que muitos de nós querem é uma forma de prática educacional cujos traços, por assim dizer, "nos planeiem”, e uma forma 
de prática educacional que permita aos estudantes aprenderem a projectar-se a eles próprios. Desta forma, pode-se dizer que, no seu melhor, a educação é o processo de tornar-se arquitecto de nossa própria educação. É um processo que não acaba até fazermos.

Elliot Eisner

A propositiva que exponho aqui, sintetizada na expressão Abordagem Espiral ${ }^{8}$ para a experiência da arte nos primeiros anos de vida, iniciou-se por meio de um insight obtido ao estudar a Abordagem Triangular, muito difundida e discutida nos mais diferentes meios da arte e educação. A Abordagem Triangular foi teorizada a partir de meados da década de 1970 e ganhou força no início da década de 1990, tendo como grande referência Ana Mae Barbosa (1991; 2010), caminho de pensamento crítico ao que se costumou nomear espontaneísmo, algo que corresponde à tal atitude adulta extremamente ingênua baseada pura e simplesmente na livre expressão, traduzida pelo dito mundo interior fazendo-se exterior, sem nenhum fio terra na história da arte, nem tampouco nos modos de produção das diferentes linguagens artísticas, contextualizados nos diferentes meios e suportes ao longo do tempo e das transformações dos modos de viver. A noção de Abordagem Triangular mostra um momento importante de estruturação de um pensamento autoral sobre o ensino de arte no Brasil, disciplina tornada obrigatória nas escolas regulares em 1971, como afirmado em sessão anterior.

Pesquisarmos, coletiva e processualmente, uma proposta que nomeio espiral e relacional para o ensino de arte de crianças pequenas, faz jus aos modos de vida das crianças hoje, e convida a retomar a conversa com as noções de espontaneidade e de criatividade obviamente sem nunca esquecer que somos, sim, seres de cultura e de história, e que, portanto, nada no âmbito artístico surgirá de maneira mágica nem tampouco inata, e que romantizar a infância como momento especial de livre expressão é algo datado e, hoje, algo insustentável. Podemos revisitar alguns dos princípios dos estudiosos da psicanálise, que puderam, por quase cem anos, trabalhar a artisticidade $^{9}$ conectada aos processos inconscientes; podemos insinuar que as crianças brincam de ser surrealistas, e que também os surrealistas romantizaram o estado da infância; podemos homenagear os estudos das possibilidades arquetípicas, e fazê-lo de forma conscienciosa - e assim por diante.

Pois foi no campo psicanalítico que Winnicott (1994) conceituou o espaço potencial, o gesto espontâneo, os objetos transicionais, e nos presenteou com uma teoria da criatividade. O espaço potencial não é um lugar concreto, é um lugar virtual, o espaço de relação entre a mãe (ou figura materna) e seu bebê, inicialmente, e, mais tarde, espaço entre a criança e outros adultos, outras crianças e o mundo. Este lugar conceitual é, para Winnicott, onde acontecem as brincadeiras imaginativas, e onde acontecerão, mais tarde, trocas significativas de outra ordem, mas semelhantes: arte, poesia, filosofia, religiosidade. Para que o espaço potencial se estabeleça, Winnicott nos diz que cada adulto deve ser como a "mãe suficientemente boa": para ele, a mãe comum em uma atitude presente e ausente, concomitantemente - presente, acompanhando seu filho, mas ausente para deixá-lo descobrir 
o mundo, a seu modo. Esta atitude desenvolve-se pelo convívio cotidiano, pelas relações de maternagem (cuidado adulto-criança). Em meu percurso nomeei essa atitude por "agachamento", nome de meu site-blog, mantido por mim desde janeiro de 2011: agachar-se é ir ao chão, onde a criança está, é a frase-síntese que o leitor encontrará por lá.

Proponho então compreendermos por Abordagem Espiral uma proposta contemporânea que, inicialmente, revisita as décadas de 1960 e 1970, de modo a demarcar, para incorporar a nossas práticas educacionais e artísticas, o começo de um processo que hoje é nomeado o fim das fronteiras entre as artes e adoção de uma metodologia processual (work-in-process) - algo que unirá forma-conteúdo, ao misturar e bagunçar os campos entre a dança e o teatro, as artes visuais e a performance, cenários repletos de teatralidades e propositivas cênicas nas instalações. São propostas neste campo: o teatro fora do teatro, a possibilidade da dança em qualquer corpo, música concebida como paisagem sonora, significações para o silêncio e o vazio, enfim, um fértil campo híbrido que, se bem explorado, levará a experiências estéticas das mais significativas, contextualizadas contemporaneamente.

Como fazer isso surgir e permanecer em nós?

Será de forma relacional, descentrada dos produtos artísticos como mercadoria, e com base em um projeto do adulto condutor dos processos expressivos, criativos, híbridos, poético-caóticos. Para abrirmos o mapa da Abordagem Espiral, vamos cultivar um tipo de desprendimento dos conteúdos artísticos a serem ensinados de forma racionalista ou hierárquica, para, assim, mergulhar no risco do desconhecido, a partir de materiais cênicos, plásticos, sonoros, corpóreos, bem como conceituais e brincantes! Mas não se trata de priorizar o processo em detrimento do produto; trata-se de cultivar a não dicotomia e criarpensar, almejando processo-e-produto, forma-e-conteúdo imbricados na própria definição do que é arte-vida. Uma possibilidade teórica para sintonizarmos é a obra Estética Relacional, livro do crítico de arte e curador francês Nicolas Bourriaud.

No livro citado encontramos um glossário onde o autor define arte como "uma atividade que consiste em produzir relações com o mundo com o auxílio de signos, formas, gestos ou objetos" $(2009$, p. 147) e, para definir artista, Bourriaud escreve que "o denominador comum entre todos os artistas é que eles mostram alguma coisa. $\mathrm{O}$ ato de mostrar basta para definir o artista, quer seja uma representação ou uma designação" (idem ibidem). Longe de simplificações, o que quero com a adoção dos modos de dizer de Bourriaud é aproximar o ensino de arte, a infância e a contemporaneidade. Ao discutir sua noção de arte relacional o autor escreve:

A possibilidade de uma arte relacional (uma arte que toma como horizonte teórico a esfera das relações humanas e seu contexto social mais do que a afirmação de um espaço simbólico autônomo e privado) atesta uma inversão radical dos objetivos estéticos, culturais e políticos postulados pela arte moderna. (Bourriaud, 2009, p. 1920)

Podemos nos desprender dos conteúdos próprios de cada especificidade artística e seus resultados tradicionais, e buscar outro olhar para o currículo em artes cujo mote por 
excelência seria o hibridismo - disse Bourriaud: "arte define-se apenas como um lugar de importação de métodos e conceitos, uma zona de hibridações" (2009, p. 143) - para tal é premente uma nova formação: algo que desafie o educador a laborar, entre teorias e práticas, sua corporalidade de professor performer, ao fazer o que gosta, mapeando sua própria história e geografia no campo compartilhado da arte, pesquisar sua poiésis; para então, na convivência com seus alunos, propor, a eles também, as pesquisas de suas poéticas pessoais. Mesmo na mais tenra infância, podemos fazer ver as pessoalidades nas produções, brincadeiras, narrativas, instalações, performances. E, como adulto, o professor pode e deve "integrar esses significantes em "territórios existenciais" pessoais" (Bourriaud, 2009, p. 128).

O primeiro material, bruto, sou eu e você. As sutilezas, os gestos de lapidação, surgirão a partir de interações entre todos, nas intersubjetividades.

Consigo trabalhar artisticamente em um espaço vazio na medida em que tenho experiência relacional, corporal, existencial. Positivar o vazio é algo extremamente precioso, e hoje talvez extremamente raro, e para tal será necessário semear modos de convivência cujas palavras-chave são: foco no outro, delicadeza, investimento amoroso e criativo. Também é primordial, pensando na primeira infância e o campo das artes, abandonar brinquedos industrializados para deixar surgir o brincar com materiais inusitados ${ }^{10}$, onde a forma será dada pelo manuseio e significatividade dada no gesto e na palavra da criança.

\section{Nota dez em poéticas próprias}

(...) Nas artes há uma ideia que o trabalho incorpora. Para os impressionistas a ideia era a luz, para os surrealistas era o inconsciente, para os cubistas era o tempo e o espaço, para os regionalistas americanos dos anos 1930 eram as vidas normais, de pessoas normais, que eram celebradas. Estes interesses forneceram a direção para o trabalho, mas a qualidade do trabalho era sempre apreciada por aquilo que fez dentro da experiência.

Elliot Eisner

Tirar dez em poéticas próprias! Como seria isso? O que poderia significar ensinar uma criança a engendrar sua poiésis? Isso é possível? Seria mesmo ensinável? Tomo por poiésis a definição do filósofo Benedito Nunes: "É produção, fabricação, criação. Há nessa palavra uma densidade metafísica e cosmológica que precisamos ter em vista. Significa um produzir que dá forma, um fabricar que engendra, uma criação que organiza, ordena e instaura uma nova realidade, um ser" (1989, p. 20).

Aconteceriam "poéticas notas 10" no compartilhar mútuo de capacidades criativas: usar os materiais de modo intenso e único, dizer em palavras como se está vivendo a dor e a delícia do momento presente, ser capaz de fazer relações na concretude material e numa temporalidade entre presente, passado e futuro... (“Vamos usar velas amanhã também?") 
Para propor a crianças pequenas uma pesquisa autoral em artes, o professor precisa, ele mesmo, ser um pesquisador de formas-conteúdos e processos-produtos que conversem com os mundos de vida e os modos de ser e estar das crianças de zero a seis anos. Quero aqui motivar o professor a uma mudança de eixo, uma saída do adultocentrismo habitual: semear uma pesquisa de vocabulário, gesto, materiais, relações entre produtos e processos em artes, de modo a questionar diretamente o modelo da educação artística parada no tempo, visão onde teatro significou apresentação de fim de ano; artes visuais significou horas e horas de trabalho em mesinhas com papel sulfite, culminando em entrega de pastas e portfólios e/ou exposições; música significou bandinha e canto coral; e dança significou passos e ensaios para festa junina e semana do folclore. Este modelo permanece, muito forte e arraigado, pelo Brasil afora. Como trabalhar diferentemente? Como operar uma radical ressignificação?

Aprendemos, por meio da leitura cuidadosa do verbete "Espiral" do Dicionário de Símbolos que a espiral é "um leitmotiv constante" e que é vista como "signo do equilíbrio dentro do desequilíbrio"; evocá-la poderá nos levar aos "ritmos repetidos da vida", ao "caráter cíclico da evolução, a permanência do ser sob a fugacidade do movimento" (Chevalier \& Gheerbrant, 1997, p. 398) - imagens poéticas fortes e que se correlacionam intensamente com a corporalidade e a vivacidade das crianças pequenas.

\section{Arte como um lugar para habitar: um outro currículo é possível}

Sob o risco de propagação de dualismos, mas a serviço da evidência, estou a falar de uma cultura de escolarização na qual está localizada uma maior importância na exploração do que na descoberta, é dado mais valor à surpresa que ao controlo, é dedicada mais atenção ao que é distintivo do que é padronizado, é dado mais interesse ao que está relacionado ao metafórico do que ao literal. É uma cultura educacional que tem maior focalização no tornar-se do que no ser, dá mais valor ao imaginativo do que ao factual, dá uma maior prioridade ao valorizar do que ao avaliar e, considera a qualidade da caminhada mais significante do que a velocidade de chegada ao destino. (...)

Elliot Eisner

Busco por um novo modo de falar com educadores da primeira infância sobre práticas em artes junto a crianças entre zero a seis anos; tenho o desafio aqui de esboçar, mesmo que de forma tênue e frágil, porque ainda individual, como seria o currículo em artes na chave contemporânea, onde mergulharemos em hibridismos - momento marcante onde as fronteiras entre as possibilidades artísticas se fragilizaram, e arte pode ser "zona de hibridações" (Bourriaud, 2009, p. 143). Bourriaud cita Guattari e nos convida a pensar que "a única finalidade aceitável das atividades humanas é a produção de uma subjetividade que auto-enriqueça continuamente sua relação com o mundo" (Guattari apud Bourriaud, 2009, p. 145). Nesta chave o fazer artístico nos leva a uma busca de "uma experiência total do pensamento" e todas as categorias artísticas são vistas como "estratégias de existência" (idem 
ibidem). Neste ponto posso dizer que a proposta da Estética Relacional de Bourriaud converge para aquilo que Merleau-Ponty demarcou como o tempo-espaço da criança pequena em seus Cursos na Sorbonne, pois ela é polimorfa e seu ser-no-mundo nos mostra um corpo total; desenhar, falar, movimentar-se, cantar, gritar, calar são formas de existir - e não atividades curriculares a executar.

A seguir, vou propor que as áreas artísticas sejam vistas como âmbitos ${ }^{11}$ - âmbitos artístico-existenciais - convidando educadores a redesenharem suas perspectivas de convivência, planejamento, propostas e avaliação, no eixo relacional. Chamo atenção do leitor para minha proposital escolha de não fazer das práticas do brincar, dos jogos e das brincadeiras, um dos âmbitos do conhecimento ou do currículo da primeira infância: pois o brincar é o âmago mais autêntico daquela perspectiva. O brincar é ação-sentimentopensamento fundante dos modos de ser e estar da criança, e será, sempre, nosso caldo, nosso veículo, nossa enzima, nosso cavalo! - presente, continuamente, nas relações entre adultos e crianças, neste modo de pesquisar, propor e avaliar - para propor novamente - aulas como atos performativos.

\section{1 Âmbito das Teatralidades: ser teatral}

Trabalhar teatralidades é algo além e aquém do ato de dar aulas, oficinas ou workshops de teatro. Gosto de definir o teatro, junto com o professor de antropologia e estudioso da performance John Dawsey ${ }^{12}$, como "ação de ver": em minha leitura da expressão, trata-se de pensar com o corpo, modular a voz, criar e recriar a máscara no rosto, pés e mãos, ser gesto e palavra encarnados nos processos de criação, cotidianamente. Algo que a criança pequena já se revela capaz: ela pratica isso tudo desde muito cedo, em suas brincadeiras.

Proponho ao adulto professor de sala procurar uma identidade de professor artista, professor performer, aproximando-se do faz de conta para observá-lo - há um caminho cênico passível de surgir na convivência das crianças que brincam imaginativamente. $\mathrm{O}$ faz de conta é uma prática das culturas da infância que trabalha com aspectos invisíveis, com combinados entre crianças, com o uso criativo de objetos, com a transformação do corpo. $\mathrm{O}$ professor que acompanha e observa as crianças brincando pode enriquecer as brincadeiras, apimentando-as com ingredientes ricos de teatralidade. São exemplos de ingredientes de um enfoque "teatralizante" para olhar o faz de conta: a busca de um espaço imaginativo - outros lugares, outros territórios, outros planetas, que delimitam uma moldura cênica, bem como a busca de um tempo ficcional ("Agora eu era..."; "Era uma vez, muito tempo atrás, muito longe daqui..."; "Quando eu era...”). As relações criança-tempo e criança-espaço, deste modo, são as aberturas para o faz de conta se expandir, dilatando-se e ampliando-se como possível teatralidade: com toda a delicadeza possível, sem imposições de resultados para tal e qual dia, hora e evento.

Também a expressividade brincante do corpo de modo integral e imaginativo, observada nas práticas do faz de conta, remete à corporificação de um "quem" (que não sou eu, mas que está em mim); sem a necessidade de continuidade ou continuísmo estrito senso, o professor 
performer e pesquisador observa as máscaras, os esboços delineados de personagens presentificados nas brincadeiras entre crianças, elas mesmas já inseridas naquele outro tempo e outro espaço; assim, é a relação criança-corpo, e sua observação, que nos dá pistas para pequenas e sutis intervenções. Exemplifico: pesquisa de trilha como paisagem sonora ${ }^{13}$ (que tal o som do disco voador? Os trovões de uma tempestade? Fogueira?); colocar ao alcance da criança objetos não estruturados (madeiras que se tornam espadas, tecidos para uma capa ou um xale para a boneca...). Assim o conhecimento que o professor veicula estará muito mais centrado no fazer das crianças que ele acompanha do que em um saber teatral formal ou espetacular: ações que possibilitarão desconstruir o adultocentrismo. A proposta é que forma-e-conteúdo teatrais estejam presentes cotidianamente, nos modos de ser e estar do adulto performer, com simplicidade, rigor e vigor.

E quando surge uma composição, a partir de combinados, de uma narrativa a ser vivida, vivenciada pelos que combinaram, o papel do adulto será permitir plena vasão da necessidade humana da invenção; saímos todos da vida cotidiana tal qual ela se apresenta, por meio de uma espécie de suspensão do tempo e do espaço realista estrito senso, e imaginamos novos mundos. Para isso - fazer arte naquela sintonia - preciso de tempo e de espaço: bastante tempo e muito espaço. E o adulto precisa estar, como já comentado na perspectiva de Winnicott, presente e ausente ao mesmo tempo: atitude que permite à criança ser o que ela é, sem nunca deixá-la perdida na noite fria ou na floresta imaginativa.

Também cabe aqui destacar a importância do ato de assistir: ser plateia, ser espectador. Durante a experiência teatral, assistir pode ser tão interessante quanto fazer; e, lentamente, o professor pode criar situações para que as crianças assistam não apenas aos colegas, mas a espetáculos profissionais bem executados e selecionados por ele, para trabalhar o repertório de experiências em teatro: um repertório de espectar.

\section{2 Âmbito das Corporalidades: ser um corpo total cotidianamente, e poder fragmentar-se no campo ficcional}

Quem hoje dúvida de que o corpo fala? E do fato de que uma autobiografia pode ser construída por crianças de modo intenso e imaginativo, não apenas como colagem de fatos, retratos e dados cronológicos, nem tampouco como simples registro do crescimento do corpo biológico? Trata-se daquilo que a psicologia sócio-contrutivista nomeou por protagonismo, e que escolhi nomear por "criança performer": podemos olhar a criança como ator social participante da vida, inserido no mundo compartilhado com o adulto; protagonista quiçá vivo, vivaz, intenso, brincante. Sua autobiografia, narrada na chave ficcional, será a mais fiel tradução de sua poética própria.

Como eu faço para indicar esse caminho para crianças?

Aponto para a busca de qualidade de movimento, clareza e novas destrezas... ação e congelamento, silêncio de corpo: pesquisa do corpo performer, narrador de si, do outro e do mundo, cujas ações-e-pensamento para performar podem ser trabalhadas, lapidadas, provocadas. Aqui o trabalho corporal não será mais composto de dancinhas, passos, 
coreografias, jogos de estátua e alongamentos... vamos além e aquém, tal como na compreensão das teatralidades. Todas as habilidades fundamentais da tradicional psicomotricidade podem ser trabalhadas de modo brincante, pessoal e biográfico: equilíbrio, tônus, lateralidade, esquema corporal, postura, atitude de atenção - traduzidos, no modo de dizer de Winnicott, por ser e ter um eu.

Referências e repertórios se ampliam, por meio de saltos e mergulhos em jogos e brincadeiras; seja por semelhança, seja por oposição, a criança experiencia gesto e linguagem, em direção a um campo antropológico rico e relacional, corporificando seu eu, percebendo a nós e ao mundo. Referências e repertórios também se dão na recepção: assistir a outras crianças, jovens e adultos, bem como companhias profissionais, dançando, faz com que a criança pertença a uma comunidade receptora.

A imaginação viva e encarnada, material como a define Bachelard (1990), imaginação das concretudes e da palavra poética, imaginação não visual mas existencial, pode ser trabalhada na primeira infância como campo de fertilizações para a artisticidade: algo que propicia chão, terra, vigas e colunas como estruturas fundantes para o conhecimento da paisagem estética; é algo em nós-com-o-outro que humaniza, proporciona expressão e construção de torres de cubos, que se transformam em portas e janelas para uma vida plena de significatividade. Ouvir a voz dos infantes! E se a criança pequena pensa com seu corpo, se é seu corpo que nos fala, será em movimento que ela nos dirá sobre si, sobre ser criança, sobre alegrias e angústias, revelando forma-conteúdo de sua poiésis.

Desde meu mestrado em Artes que formulei três tipos de corporalidades para a primeira infância: o corpo-rabisco, o corpo-figura e o corpo-narrativa (Machado, 2004). Não se trata de algo evolutivo, mas antes, três modos de ser e estar que observei em meus alunos entre cinco e seis anos de idade, ao longo de dezesseis anos de experiência. Por corpo-rabisco entendo um corpo quase só pura energia; o corpo-figura é aquele que se mostra em jogos de estátua, em situações cotidianas bem delimitadas (filas, esperas, momentos de contenção), e o corpo-narrativa é aquele que desenha no espaço, transpassa, ocupa, percorre um caminho tal como o percurso de obstáculos: para além do salto e da corrida (pura energia), para além da capacidade de congelar seu corpo em um animal, coisa ou pessoa (jogos de estátua), a corporalidade da criança, quando o adulto permite, traça e conduz histórias, mescla dados biográficos factuais com intersubjetividade intensa, e nos diz algo sobre quem a criança é: a criança, ela mesma, não se sente "criança".

A criança, em situações de vida corporal plena, é uma pessoa que tem muito a nos ensinar: por menos experiência cronológica que tenha, dois ou três anos de vida revelam a sabedoria do frescor de ser-no-mundo.

\section{3 Âmbito das Espacialidades: ser móvel, polimorfo, modelável, plástico}

O trabalho com desenho, construções, pintura, argila, quadrinhos, painéis e tudo o mais enriquece o conhecimento da corporalidade, do outro e do mundo, e me chama para a concretude do brincar na chave da teatralidade (usufruto do corpo e dos objetos e seus 
contextos criados para brincar). Como comentado na introdução, isso é o que muitos chamam de integração de linguagens artísticas, passos de gigante na direção do hibridismo. Tornar-se apto a criar sua poética pessoal - cotidianamente, e não para uma exposição! - é pesquisar tudo que é intrínseco à união forma-conteúdo, em suas emoções, reflexões e conhecimentos. E também há que saber do vazio: e permitir-se entrar nele, real e existencialmente.

A corporalidade não se separa nem do tempo nem do espaço vividos, nem tampouco do mundo ao redor ou da cultura local; nesse sentido, não haveria indivíduo: há corporalidades, ou seja, pessoalidades em relação, seres-no-mundo em processos de descoberta e encontro. A plasticidade de si e do mundo transformadas espacialmente em desenhos, ambientações, objetos, instalações e painéis... são as possíveis presentificações dos seres-no-mundo, a partir do questionamento do que, tradicionalmente, se chamaram as "artes visuais". Também experimentações táteis, audíveis, olfativas, palatáveis fazem parte do campo estético. Que tal poder renomear as artes, antes visuais, por sensoriais?

E ainda podemos ir mais longe, como convidou Bourriaud, e redefinir as artes como campo de "reciclagem do dado cultural" (Bourriaud, 2009, p. 19); o que nos restaria seriam superfícies, volumes, dispositivos. Volto a referendar as práticas do faz de conta, e convido o leitor a lembrar-se da sua infância e das crianças com as quais convive, e as possíveis situações de cabanas: colocar-se debaixo dos móveis, arrumar ritualisticamente uma pista no chão para corrida de carrinhos, dar banho em bonecas num banheiro imaginário... As espacialidades estão entre você e eu, entre a criança e seu adulto cuidador, entre um e todos.

Cabe ao professor performer disponibilizar os mais diferentes materiais; instalar ganchos ao alcance das crianças onde barbantes e varais surgirão pela necessidade do momento; colecionar e disponibilizar materiais tais como madeiras, tecidos, latas e papéis, restos e refugos para além do plástico, reciclando lixos urbanos, transformando materiais não estruturados em brinquedos e objetos para brincadeiras. Surgem, mais e mais, novos mundos - e, com eles, novas possibilidades de ser e estar. E convidamos todos ao mergulho, à tangente, à paralela, à perpendicular... dos fenômenos estéticos vividos, mostrados, experienciados. Fim da linha e da união de dois pontos como vocabulário inicial do que é desenho.

E para pensar um horizonte de expectativas para adquirir repertório, cabe sempre visitas aos museus, mas também aos edifícios arquitetônicos marcantes, a exposições onde é permitido mexer nos objetos e entrar nas instalações, percepções dos muros e grafites da cidade, e ainda poder ver em vídeo, cinema e outras mídias propositivas de cenários e paisagens inusitadas de artistas gráficos e performers... enfim, há uma riqueza de referências esperando pelas crianças pequenas.

\section{4 Âmbito das Musicalidades: ser sonoro, e capaz do silêncio}

Entendeu-se na educação da primeira infância, por muito tempo, música como a habilidade de cantar e tocar um instrumento, gerações afora, o que consolidou a tradição das bandinhas e do canto coral, bem como músicas cantadas com gestos ensinados por imitação, 
e escuta de música gravada (para quem não sabe cantar nem tocar?). Proponho outra afinação: crença na musicalidade como um aspecto da corporalidade de todos; aqui, o convite é instrumentalizar-se, sim, mas para ouvir e ser ouvido, ocupar espaços, recriar tempos. Deixemos surgir algo como as artes da musicalidade, pela retomada da significação ritual do canto e sua união com o movimento e a teatralidade, sem propor a imitação como método, mas antes, a presentificação de estados e atmosferas. Isso os bebês fazem, estão aptos.

O professor performer procurará positivar cada fenômeno infantil, o grito e o balbucio, o jargão ou blablação, fervidos, em ebulição, num caldo de expressividade. $O$ adulto fala, canta, conversa, silencia, mostra a vida para quem é iniciante nela e revela o mundo da música, na medida em que a criança se interessa por ele. A música está no ar: não no especialista musicista, nem no CD infantil. Aliás, a estereotipia contida no senso comum daquilo que é definido por música infantil deve ser evitado, a todo custo, de modo a poder trabalhar noutra chave.

A música está na nossa conversa e no nosso ruído... No latido do cachorro, no miado do gato, em tudo que ouço e recrio, nas significações que dou para sonoridades encontradas na natureza, chuva, raio e trovão. Ser musical no corpo e nas relações, na lida com os meios e com os materiais: voz, ruídos, onomatopeias, sons de todos os objetos cotidianos... toque e batuque comunicando algo a alguém.

Aquietar-se para apreciar o silêncio. Saber ficar só.

Reinventar a própria escuta: alio escuta e imaginação, desenvolvo habilidades sutis, sensibilidade para pequenas e grandes percepções sonoras. Vamos em que ritmo pular a amarelinha? A intensidade do elástico para pular está boa? Qual o timbre do tambor no circo? Ouviste o rugido do leão?

Grandes músicos, intérpretes e compositores, nos ensinaram a riqueza imagética contida na música. As crianças, quando levadas para dentro de uma riqueza de repertórios, se mostram extremamente aptas e sensíveis para enxergar as imagens musicais - mesmo as mais sofisticadas, interpretando-as a seu modo - e também para criá-las. Aí sim propomos a escuta de gravações profissionais. E amadoras também.

As crianças podem, e merecem, habitar um lugar muito maior, ao mesmo tempo mais audacioso e provavelmente mais confortável para elas, para além da indústria cultural adulta voltada para elas. Crianças são improvisadoras em potencial, e podemos considerar a improvisação como algo próprio do aprendizado musical, seu meio: não como talento, mas pela presentificação de estados que a escuta, o diálogo e a transformação que o conhecimento musical revelado em paisagens sonoras proporcionam. Nessa sintonia, a escuta doa significações e abre acesso a vias de tempos e espaços do estado de música, pela memória sonora, imaginativa e vivencial, de nosso ser-no-mundo. (Ouviste o rugido do leão?)

\section{Para concluir, sobrevoo e mergulho na Espiral}

Quero, por meio da publicação deste artigo, propor discussão e construção coletiva de uma possível Abordagem Espiral para compreender a experiência da arte na pequena 
infância, no diálogo com as práticas já estabelecidas pela Abordagem Triangular, modo de trabalhar exaustivamente discutido nos mais diferentes meios da Arte e Educação brasileira. Do mesmo modo que a tradição dos Jogos Teatrais de Viola Spolin (1999), segundo a própria autora, não é pertinente para as crianças pequenas, pelo seu aspecto metodológico intelectual e organizativo, também a Abordagem Triangular, cujos vértices dimensionam-se na ampliação das referências culturais (produção artística contextualizada nas culturas visuais, foco na estética, na crítica, na história da arte), talvez não tenha atingido, em sua perspectiva concretizada por adultos, suficientes leveza e intensidade dialógicas com as maneiras de ser da criança de zero a seis anos. Penso que há, com crianças de zero a seis anos, riscos perigosos de intelectualização da experiência vivida quando o professor, focado naquela abordagem, encarna um elemento analítico, ao discutir e comparar desenhos, por exemplo, pretendendo ensinar algo sobre a história do grafismo ou da pintura para as crianças de três ou quatro anos. A primeira infância, nos dizeres de Merleau-Ponty, é um momento de vida préreflexivo: não faria sentido "discutir" sua própria produção gráfica, nos anos iniciais - esta seria uma demanda adulta.

Por outro lado, ouvi também quem se utilizasse dos argumentos de Duarte Junior de que a tenra infância é momento de vida de estesia, e não de experiência estética estrito senso, e que, ao definir a arte como "entrada na metáfora" (Duarte Junior, 2001, p. 13) - algo que, em tese, implica distanciamento de si e do mundo - o empenho em construir um pensamento sobre educação estética nos primeiros anos de vida se revelaria como um erro conceitual, talvez até um desperdício de energia adulta. Penso que este tipo de formulação minimizou a complexidade da questão, negativando a experiência das crianças de zero a seis anos e lidando, inclusive, com as noções filosóficas de Duarte Junior de modo atravessado - uma vez que o próprio autor argumenta, em contraposição à atividade intelectualizada ou técnica da arte, uma retomada da "educação (do) sensível” (idem ibidem).

Hoje penso que outra visada para o ensino de arte pode fazer jus à retomada de conversa entre as noções de espontaneidade e criatividade, sem nunca esquecer que somos, sim, seres de cultura e de história, e que, portanto, nada no campo da educação surgirá de maneira mágica, nem tampouco inata ou subjetivista. É meu ponto de vista que a propositiva em espiral seria, inicialmente, uma espécie de reconciliação com os anos dos óculos espelhados - evidentemente sem a crença ingênua de que nos tornaremos, da noite para o dia e em retrocesso, beatniks ou hippies - mas com vistas sim a um tipo de conexão direta entre arte e vida.

Quero entrar na máquina do tempo com você, espiralando nossos corpos pelo túnel, para irmos até as décadas de 1960 e 1970, de modo a demarcar o começo de um processo que hoje é nomeado o fim das fronteiras entre-artes - algo que uniu forma-conteúdo e que leva à mistura e bagunça dos campos fronteiriços entre a dança e o teatro, as artes visuais e a performance, possibilitando cenários repletos de teatralidades e propositivas cênicas dentro de instalações; teatro fora do teatro, dança em qualquer corpo, música como paisagem sonora, silêncio e vazio, enfim, um fértil campo híbrido que, se bem explorado, levará a todos na direção de experiências estéticas das mais significativas, contextualizadas no que se diz contemporâneo, o espírito próprio de uma época, como disse Veras (2007). 
Como fazer isso acontecer e permanecer, transformando-se, ao longo do tempo? E como fazer isso acontecer suficientemente perto das crianças pequenas?

Acontecerá de forma relacional e com base em projetos do adulto performer, iniciador/instigador da faísca dos processos artísticos, expressivos, criativos a acontecerem entre ele e as crianças, entre crianças, entre crianças e mundos de vida. Serão possíveis os mais diferentes hibridismos ao adotarmos a metodologia do trabalho em processo, work-inprocess, sem ansiar por produtos finais acabados ou considerados bem feitos, mas antes, dedicando-nos a processos de elaboração e criação: projetos, rabiscos, garatujas e figuras de memórias mixadas com propositivas adultas para roteiros de aulas/atos performativos junto às crianças.

Quem quiser percorrer a espiral precisará cultivar um tipo de desprendimento dos conteúdos a serem ensinados de forma racionalista e linear, para saltar e mergulhar no risco do desconhecido, a partir de materiais cênicos, plásticos, sonoros, corpóreos, bem como conceituais e brincantes! Para desapegar-se dos conteúdos específicos de cada modalidade artística, o educador pode experienciar um novo tipo de formação: uma formação que o desafie a mapear sua própria geografia no campo compartilhado da arte, para pesquisar, com engajamento e profundidade, sua poiésis - e então, na convivência com seus alunos, propor a eles mesmos as pesquisas de suas poéticas pessoais. A metodologia necessária remete ao mergulho da gaivota no oceano, como imaginou Merleau-Ponty: em contraposição ao simples sobrevoo, situação na qual estaríamos distanciados e munidos de ferramentas analíticas e categoriais. Lembremos: a primeira infância é um tempo pré-reflexivo.

Faz-se necessária uma ampla discussão curricular, adotando a postura daquele que acredita que o currículo é discurso político e possui poder de transformar as escolas naquilo que elas podem ser. Adoto o dizer de Elliot Eisner de que a arte nos fornece novas "formas de pensar" e de que é preciso criar, nas palavras dele, "uma nova cultura de escolarização", conforme epígrafe em sessão anterior.

E como também já dito, o primeiro material, bruto, sou eu e você, no mundo. As sutilezas surgirão a partir de interações entre todos. A arte mesma é que estreitará o espaço das relações. Um currículo menos setorizado, menos emoldurado pelas teorias desenvolvimentistas que nos levam a atividades por faixas etárias e mais próximo das crianças como elas vivem hoje, possibilitando um professor extremamente atento às culturas da infância, que perceba novas formas-conteúdos e que se desapegue, sem escrúpulos, das práticas às vezes tão arraigadas onde música seria sinônimo de cantar com gestos, teatro representaria comemoração (de quê?), artes visuais demandaria exposição e dança se traduziria por coreografia.

Convido o professor a permitir que as crianças dancem no banho de esguicho, que conheçam "o barro debaixo do chão" tal como na canção De onde vem o baião - na canção, no corpo, no bolinho de lama; que sejam, imaginativamente, animais e coisas em seus corpos, que construam instalações ao transformar o brinquedo ou revestir a árvore do parque com argila ou papel celofane; que possam ouvir também a canção Refazenda, brincando pelo espaço da sala, sem pressuposto de contenção! E cenas, textos, pinturas, gestos, movimentos, bonecos, som e silêncio, poderão surgir: "Abacateiro / acataremos seu ato / nós também 
somos do mato / como o pato e o leão / Aguardaremos / brincaremos no regato (...)" (Gilberto Gil, Refazenda, 1975). (Ouviste o rugido do leão?)

E como organizar tudo isso de forma adulta e madura, de modo sério e digno, um currículo brincante a ser reconhecido pelo Ministério da Educação e por outras instâncias que chancelam currículos no país? Os passos futuros desta propositiva residem na discussão ampla e democrática de um currículo em educação estética durante a pequena infância, bem como a formação de professores nesta chave, de modo a refletir sobre seu papel fundamental na iniciação em artes - e agir. Lembramos o leitor que o currículo brasileiro, representado no momento pela Base Nacional Comum Curricular, não supõe o ensino de arte estrito senso na Educação Infantil. Esta discussão aberta, aliás, dá ensejo a um outro artigo.

Acontecerá mudança por meio de debate e validação das ideias híbridas; será por meio de discussão sobre políticas públicas em arte e educação que trabalhem a partir do modo de ser da criança pequena: onírica, polimorfa, não representacional. A compreensão profunda da simplicidade destas noções há que revelar-se na corporalidade dos educadores: o que gera a necessidade de um grande movimento de formação pela transformação. Assim surgiria uma formação que faça espiral com os estudos das culturas da infância, gerando um saber contextualizado acerca da Sociologia da infância e da Antropologia da criança, práticas-etextos, manutenção de Diários de Bordo como etnografia da experiência vivida com as crianças, tudo, enfim, unindo forma-conteúdo artístico. Imagino espaços formativos onde adultos concretizem sua própria visão de infância, enriqueçam seus recursos imaginários, busquem fazer pontes e interligações entre arte e filosofia, arte e cotidianeidade, gerando e fazendo circular sua poiésis, em sintonia com as relações entre infância e arte contemporânea. Planejar, propor, avaliar e retomar novas propostas também ganhariam novas dimensões, partindo dos contextos vividos e situacionais das crianças mesmas.

O trabalho cuidadoso, em cada âmbito artístico-existencial, ao longo da primeira infância, ganhará significação quando experienciado pelas crianças acompanhadas pelos adultos na sintonia do brincar e do imaginar, capacidades humanas que criam entradas e saídas para os labirintos e conflitos do enfrentamento de si, do outro e do mundo. Labirintos que, se desenhados e construídos de modo polimorfo, onírico e não representacional, serão percorridos por dois pés de criança, vestidos por dois sapatos: arte e vida.

\section{Remate}

Este artigo foi escrito na forma de ensaio para o Concurso Mário Pedrosa no segundo semestre de 2011 e revisto e ampliado no primeiro semestre de 2020, durante a pandemia mundial do novo coronavírus. Observo que uma proposta espiral concretizada com a necessária vivacidade, vigor e rigor, para ser implementada, precisará de ampla discussão sobre o futuro das relações entre crianças, entre crianças e adultos, e das crianças com seus mundos de vida. Atento ao risco grave de um enorme retrocesso à prerrogativa historicamente denominada por higienista, na qual, grosso modo, as crianças pequenas deveriam entrar e sair das creches de modo organizado, limpo, ordenado, sem vivenciar 
quaisquer riscos nem apresentar manchas nas roupas. Isso se dará, obviamente, pelo temor de contaminação e adoecimento. Quiçá seja garantido o direito às crianças ao brincar, criar e performar, em novas formas-conteúdo, nunca antes imaginadas.

\section{Notas}

1. Nascido na Argentina, Ilo migrou para o Brasil em 1960; participou intensamente do movimento das Escolinhas de Arte do Brasil ao lado de Augusto Rodrigues, Anísio Teixeira, Ferreira Gullar e Nise da Silveira, na Escolinha do Rio de Janeiro. Ilo faleceu na cidade de São Paulo, em setembro de 2019.

2. Alguns anos depois de estar trabalhando com a expressão "abordagem espiral" e o ensino de arte, descobri que nos Estados Unidos a expressão "currículo espiral" já existia há décadas, algo ligado à contribuição do importante pesquisador Jerome Bruner, falecido em junho de 2016 (mas ativo na Universidade de Nova Iorque até mesmo depois dos seus 90 anos). No entanto, por "abordagem espiral” não dou o mesmo sentido que Bruner, pois, para ele, o currículo em espiral, grosso modo, repete conteúdos, em níveis de aprofundamento conforme as crianças e jovens crescem e ganham novas habilidades e competências - a espiral, para Bruner, aconteceria como numa espécie de adensamento das mesmas aprendizagens. Já o uso que faço da palavra "espiral" designa um ir e vir, ascendente e/ou descendente, dos campos dos saberes em arte, "âmbitos artístico-existenciais" agora misturados, brincantes, híbridos e intercomunicantes.

3. Minha pesquisa de pós-doutorado, desenvolvida em 2009 (ECA/USP com bolsa FAPESP) e intitulada Territórios do brincar teve como resultados um artigo (Machado, 2010a) e um livro (Machado, 2018).

4. A tese tornada livro foi editada para a coleção Os Filósofos e a Educação (Machado, 2010b).

5. Na contemporaneidade, a Sociologia da infância formula um novo discurso sociológico onde o campo dos laços sociais e das dimensões subjetivas, antes próprio apenas da Psicologia, é relevante para que as crianças possam ser "analisadas no processo de socialização e não como destinatários passivos da socialização adulta" (Sarmento, 2004, p. 20) - nessa chave surge o entendimento das crianças como atores sociais, bem como o âmbito dos estudos culturais da infância ou as assim chamadas "culturas da infância" como categoria sociológica.

6. Cabe explicitar que buscar o gesto criativo e espontâneo não é sinônimo de "espontaneísmo" mas, antes, busca de algo que pode ser considerado inesperado, improvável. Seria um acontecimento próximo daquilo que Merleau-Ponty formula como expressividade; comentando o desenho infantil, o filósofo disse: "devemos tomar o termo "expressão" em seu sentido pleno, de junção entre aquele que percebe e a coisa percebida; não confundi-lo com a fabricação de uma simples cópia. Aliás, a lei de todo desenho é exprimir as coisas e não assemelhar-se a elas (...)”. (1990a, p.220) O gesto espontâneo revela a comunicação mais direta e autêntica, pré-reflexiva, da criança consigo, com o outro, com o mundo.

7. Desde minha pesquisa de mestrado, entre 1999 e 2001, me dedico a discutir o valor dos Diários de Bordo na pesquisa em artes. Ver Machado (2002).

8. A simbologia da espiral é rica e interessante: segundo o Dicionário de Símbolos, evoca "a evolução de uma força, de um estado"; "é um tema aberto e otimista - partindo de uma extremidade dessa espiral, nada mais fácil do que alcançar a outra extremidade". A espiral "é e simboliza emanação, extensão, desenvolvimento, continuidade cíclica mas em progresso, rotação criacional” (Chevalier \& Gheerbrant, 1997, p. 397-398).

9. Gosto da maneira do dramaturgo Pedro Barbosa definir artisticidade e arte: "revela-se como forma peculiar, mas irrecusável, da indagação do real e de compreensão de nossa relação com a Vida. Por outras palavras: um verdadeiro ato de conhecimento a que chamaremos cognição estética. (...) uma via cognitiva de captação profunda da nossa relação com a Vida" (Barbosa, 1996, p. 90).

10. Materiais inusitados são hoje denominados por "materiais não estruturados", e foram designados por mim "brinquedossucata" em meu primeiro livro (Machado, 1994).

11. Imaginem que é próprio da existência dos entes humanos o fazer artístico. E nessa imaginação localizem âmbitos: lugares, modos de habitar. Teatralizar. Espacializar. Corporeificar. Musicalizar. Os verbos desenhados como mapas: lugar das teatralidades; lugar das espacialidades; lugar das corporalidades; lugar das musicalidades. Agora misture os lugares, como se fossem serpentinas que se espiralam. Pronto: você concretizou, por meio das minhas "instruções de jogo", a abordagem espiral no ensino das artes, concebidas como âmbitos artístico-existenciais.

12. Segundo o professor, sua definição se dá a partir da leitura da obra de Roland Barthes. 
13. Paisagem sonora é um termo advindo da obra do pesquisador canadense Murray Schafer (2018) - tradução para soundscape. Sua obra está traduzida no Brasil com ampla divulgação nos meios da educação musical.

\section{Referências}

BACHELARD, G. A Terra e os Devaneios do Repouso: Ensaios sobre as imagens da intimidade. São Paulo: Martins Fontes, 1990.

BARBOSA, A. M. A imagem no ensino da arte: Anos 80 e novos anos. São Paulo/Porto Alegre: Perspectiva/Iochpe, 1991.

BARBOSA, A. M. \& CUNHA, F. P. (Org.). Abordagem Triangular no ensino das artes e culturas visuais. São Paulo: Cortez, 2010.

BARBOSA, P. Metamorfoses do Real: Arte, imaginário e conhecimento estético. Porto: Edições Afrontamento, 1996.

BOURRIAUD, N. Estética Relacional. São Paulo: Martins Fontes, 2009.

CHEVALIER, J.; GHEERBRANT, A. Dicionário de Símbolos. Rio de Janeiro: José Olympio Editora, 1997.

COUTINHO, R.; PETERSON, S. Abordagem Triangular: ziguezagueando entre um ideário e uma ação reconstrutora para o ensino de artes. Revista GEARTE. Porto Alegre, v. 4, n. 2, p. 282-294, mai./ago. 2017.

DUARTE JUNIOR, J. F. O sentido dos sentidos: a educação (do) sensível. Curitiba: Criar Edições, 2001.

EISNER, E. O que pode a educação aprender das artes sobre a prática da educação?. Currículo sem Fronteiras, v. 8, n. 2, p. 5-17, jul./dez. 2008.

KAPROW, A. Essays on the blurring of art and life: expanded edition. Berkeley: University of California Press, 2003.

MACHADO, M. M. O brinquedo-sucata e a criança / A importância do brincar, Materiais e atividades. São Paulo: Edições Loyola, 1994.

MACHADO, M. M. O diário de bordo como ferramenta fenomenológica para o pesquisador em artes cênicas. Sala Preta, v. 2, 260-263, 2002.

MACHADO, M. M. Cacos de infância / Teatro da solidão compartilhada. São Paulo: FAPESP, Annablume, 2004.

MACHADO, M. M. A criança é performer. Educação \& Realidade, v. 35, n. 2, p. 115-137, mai./ago. 2010a.

MACHADO, M. M. Merleau-Ponty \& a Educação. Belo Horizonte: Autêntica Editora, 2010b.

MACHADO, M. M. Fim do infante / Três processos dramatúrgicos. Rio de Janeiro: Circuito, 2018.

MENKE, C. Force: A Fundamental Concept of Aesthetic Anthropology for Radical Philosophy. New York: Fordham University Press, 2013.

MERLEAU-PONTY, M. Merleau-Ponty na Sorbonne/Resumo de Cursos/

Filosofia e Linguagem. Campinas: Papirus, 1990a.

MERLEAU-PONTY, M. Merleau-Ponty na Sorbonne/Resumo de Cursos/ Psicossociologia e Filosofia. Campinas: Papirus, 1990b.

NUNES, B. Introdução à filosofia da arte. 2. ed. São Paulo: Ática, 1989.

READ, H. A redenção do robô: Meu encontro com a educação através da arte. São Paulo: Summus Editorial, 1986.

SARMENTO, M. J. As culturas da Infância nas Encruzilhadas da $2^{\text {a }}$ Modernidade. In Crianças e miúdos: perspectivas sociopedagógicas da infância e educação. Porto: Asa, 2004.

SCHAFER, M. Ouvir Cantar: 75 exercícios para ouvir e criar música. São Paulo: UNESP, 2018. 
SLADE, P. O jogo dramático infantil. São Paulo: Summus Editorial, 1978.

SPOLIN, V. Improvisation for the theater. Illinois: Northwestern University Press, 1999.

VERAS, L. Quem tem medo de arte contemporânea? Revista Continuum, São Paulo, n. 19, p. 7-10, 2007.

WINNICOTT, D. W. Playing and reality. London/New York: Tavistock/Routledge, 1994.

\section{Correspondência}

Marina Marcondes Machado: Artista-professora, doutora em Psicologia da Educação com pós-doutorado em Pedagogia do Teatro. Docente na Licenciatura em Teatro e na pós-graduação em Artes da Universidade Federal de Minas Gerais (UFMG).

Website: https://www.agachamento.com

E-mail: mmjm2012@ufmg.br

Texto publicado em Currículo sem Fronteiras com autorização da autora 